\title{
PENEGAKAN HUKUM TERHADAP TINDAK PIDANA PENCEMARAN NAMA BAIK MENURUT PASAL 27 AYAT (3) UNDANG-UNDANG NOMOR 11 TAHUN 2008 TENTANG INFORMASI DAN TRANSAKSI ELEKTRONIK (UU ITE)
}

\author{
Bambang Sutrisnoํ, FX Bhirawa Braja Paksa ${ }^{2}$
}

\begin{abstract}
ABSTRAK
Penggunaan teknologi internet juga tidak dapat dipungkiri membawa dampak negatif yang tidak kalah banyak dengan manfaat positif yang ada. Internet dapat menimbulkan kejahatan seperti pengancaman, pencurian, pencemaran nama baik, pornografi, perjudian, penipuan hingga tindak pidana terorisme. Melalui media internet beberapa jenis tindak pidana tersebut dapat dilakukan secara online oleh individu maupun kelompok dengan resiko tertangkap yang sangat kecil dengan akibat kerugian yang lebih besar baik untuk masyarakat maupun negara. Fenomena tindak pidana teknologi informasi merupakan bentuk kejahatan yang relatif baru apabila dibandingkan dengan bentuk-bentuk kejahatan lain yang sifatnya konvensional.

Hasil penelitian menunjukkan bahwa Modus operandi yang dilakukan oleh pelaku tindak pencemaran nama baik melalui media sosial, merupakan salah satu cerminan bahwa masyarakat Indonesia belum memahami makna penggunaan media sosial secara baik dan bertanggung jawab. Selain mempunyai hak kita juga harus mengetahui kewajiban apa saja yang harus kita laksanakan sebelum mendapatkan hak tersebut, sama halnya dengan menggunakan media sosial, penggunaan media sosial merupakan hak tiap-tiap masyarakat pada saat ini, namun sebagai penggunanya tentu kita juga harus mengetahui kewajiban untuk mengharagai orang lain. Banyaknya modus operandi yang digunaan oleh pelaku cyber crime, maka perlunya kehati-hatian dalam menggunakan media sosial agar kita tidak menjadi salah satu dari pelaku yang dapat merugikan orang banyak. Dalam UndangUndang Nomor 11 Tahun 2008 tentang Informasi dan Transaksi Elektronik, tidak diatur secara jelas memahami batasan dalam kebebasan berpendapat. Jika kita melihat impelementasinya seakanakan diatur, maka jelas bahwa kita benar-benar membutuhkan aturan yang baru tentang tindak pidana pencemaran nama baik dalam undang-undang Informasi dan Transaksi Elektronik. Bagi masyarakat harus lebih mehami arti kebebasan berpendapat yang diberikan oleh negara, dan menggunakan kebebasan tersebut dengan bertanggung jawab. Bukan untuk membatasi kebebasan tersebut melainkan untuk memberi peringatan atau tindakan Preventif bagi masyarakat agar lebih berhati-hati dalam menggunakan media sosial dalam berkomunikasi dan memberikan tindakan Represif bagi pelaku tindak pidana pencemaran nama baik melalui media sosial.
\end{abstract}

Kata Kunci: Penegakan Hukum, Tindak Pidana, Pencemaran Nama Baik, UU ITE

\section{A. PENDAHULUAN}

Pencemaran nama baik di dalam dunia maya yang terjadi sehingga penggunaan Kitab Undang-undang Hukum Pidana (KUHP) sebagai salah satu penyelesaian masalah dianggap perlu didukung atau ditunjang dalam pelaksanaannya yaitu dengan Undangundang Informasi dan Transaksi Elektronik (UU ITE).

Menurut bahasa Indonesia, pencemaran nama baik dapat diartikan sebagai perbuatan yang menodai atau mengotori nama baik (seseorang). Sedangkan, menurut frase bahasa inggris, pencemaran nama baik diartikan sebagai defamation (fitnah), slander, libel. Slander adalah oral defamation (fitnah secara lisan), sedangkan libel adalah written defamation (fitnah secara tertulis). 1

Menurut, Kitab Undang-undang Hukum Pidana (KUHP) dikenal dengan istilah "penghinaan" (Pasal 310 KUHP) yang pada umumnya didefinisikan: "suatu tindakan yang merugikan nama baik dan kehormatan seseorang." 2

Tindak pidana pencemaran nama baik tidak mengenal batas wilayah serta waktu kejadian karena korban dan pelaku sering berada di negara yang berbeda. Tindak pidana tersebut dapat dilakukan hanya dari

${ }^{1}$ Wawan Tunggal Alam, Pencemaran Nama Baik di Kebidupan Nyata dan Dunia Internet, wartapena, Jakarta, 2012, Hlm. 7

${ }^{2}$ Ibid., Hlm. 7 
depan komputer yang memiliki akses Internet tanpa takut diketahui oleh orang lain/saksi mata, sehingga kejahatan ini termasuk dalam Transnational Crime (kejahatan antar negara yang pengungkapannya sering melibatkan penegak hukum lebih dari satu negara). Jadi, dapat disimpulkan bahwa kejahatan informasi teknologi/Cybercrime memiliki karakter yang berbeda dengan tindak pidana umum baik dari segi pelaku, korban, modus operandi dan tempat kejadian perkara.

Kemajuan cara berpikir manusia dan perkembangan teknologi informasi yang memberikan dampak negatif tersebut, harus diantisipasi dan ditanggulangi dengan hukum yang terkait dengan pemanfaatan teknologi informasi dan komunikasi. Secara internasional hukum yang terkait kejahatan teknologi informasi digunakan istilah hukum siber (cyber law). Istilah lain yang juga digunakan adalah hukum teknologi informasi (law of information technology), hukum dunia maya (virtual world law), dan hukum mayantara. ${ }^{3}$ Sehubungan dengan tindak pidana di dunia maya yang terus berkembang, pemerintah telah melakukan kebijakan dengan terbitnya Undang-undang No.11 Tahun 2008 tentang Informasi dan Transaksi Elektronik (UU ITE) yang diundangkan pada tanggal 21 April 2008. Dalam undang-undang tersebut terdapat beberapa pasal pidana yang merupakan ketentuan tindak pidana khusus di samping berlakunya Kitab Undang-undang Hukum Pidana (KUHP) sebagai undangundang tindak pidana umum. Undangundang Informasi dan Transaksi Elektronik (UU ITE) juga merupakan pedoman hukum pertama yang mengatur khusus terhadap dunia maya (cyber law) di Indonesia.

Substansi/materi yang diatur dalam Undang-undang Informasi dan Transaksi Elektronik (UU ITE) ialah menyangkut masalah yurisdiksi, perlindungan hak pribadi, azas perdagangan secara e-commerce, azas persaingan usaha-usaha tidak sehat dan perlindungan konsumen, azas-azas hak atas kekayaan intelektual (HAKI) dan hukum Internasional serta azas Cybercrime. Menurut Undang-undang Informasi dan Transaksi Elektronik (UU ITE) dimuat ketentuan-

3 Penjelasan umum Undang-undang Nomor 11 Tahun 2008 tentang Informasi dan Transaksi Elektronik ketentuan mengenai larangan melakukan tindak pidana. Undang-undang tersebut menetapkan beberapa perbuatan yang dikriminalisasi sebagai tindak pidana komputer dengan sanksi-sanksinya. Menurut Bab VII Undang-undang Informasi dan Transaksi Elektronik (UU ITE) tersebut menentukan perbuatan-perbuatan tertentu yang dilarang untuk dilakukan. Perbuatanperbuatan tersebut ditentukan di dalam Pasal 27 sampai dengan Pasal 37, Bab XI yang terdiri atas Pasal 45 sampai dengan Pasal 52 menentukan kriminalisasi terhadap perbuatan-perbuatan yang dalam Bab VII ditentukan sebagai perbuatan-perbuatan yang dilarang beserta masing-masing sanksi pidananya. Salah satu tindak pidana komputer yang diatur oleh Undang-undang Informasi dan Transaksi Elektronik adalah tindak pidana pencemaran nama baik dengan menggunakan sistem komputer yang diatur dalam Pasal 27 ayat (3) dan diancam sanksi pidana berdasarkan Pasal 45 ayat (1). Rumusan pasal 27 ayat (3), yang berbunyi ;

"Setiap orang dengan sengaja dan tanpa hak mendistribusikan dan/atau mentransmisikan dan/atau membuat dapat diaksesnya Informasi Elektronik dan/atau dokumen elektronik yang memiliki muatan penghinaan dan/atau pencemaran nama baik".

Rumusan pasal 45 ayat (1), yang berbunyi ; "Setiap orang yang memenuhi unsur sebagaimana dimaksud dalam Pasal 27 ayat (1), ayat (2), ayat (3), atau ayat (4) dipidana dengan pidana penjara paling lama 6 (enam) tahun dan/atau denda paling banyak Rp 1.000.000.000,00 (satu miliar rupiah)".

\section{B. METODE PENELITIAN}

\section{Jenis Penelitian}

Jenis penelitian yang digunakan penulis dalam tesis ini adalah jenis penelitian hukum yang dipandang dari sudut tujuan penelitian hukum yaitu penelitian yuridis normatif, yaitu penelitian yang dilakukan dengan cara pengkajian peraturan perundang-undangan dan bahan pustaka atau data sekunder yang ada. ${ }^{4}$

\footnotetext{
4 Johnny Ibrahim, Teori dan Metode Penelitian Hukum Normatif, Bayumedia Publishing, Jakarta, 2005, Hlm. 241
} 


\section{Pendekatan Masalah}

Pendekatan penelitian yang dipakai yaitu pendekatan perundang-undangan (statue approach) 5 maksudnya penelitian berdasarkan pada teori-teori yang sesuai dengan Undangundang Nomor 11 Tahun 2008 Tentang Informasi dan Transaksi Elektronik (UU ITE).

\section{Sumber Bahan Hukum}

Data yang berasal dari bahan-bahan hukum sebagai data utama yang diperoleh dari pustaka, antara lain :

\section{a. Bahan hukum Primer}

Bahan hukum yang mempunyai otoritas (autoritatif) yang terdiri peraturan perundang-undangan 48 , antara lain : ${ }^{6}$

1) Undang-undang Nomor 1 Tahun 1946

Tentang Kitab Undang-undang Hukum Pidana.

2) Undang-undang Nomor 11 Tahun 2008 Tentang Informasi dan Transaksi Elektronik.

\section{b. Bahan Hukum Sekunder}

Bahan Hukum Sekunder yaitu bahan hukum yang memberikan penjelasan mengenai bahan hukum primer, seperti rancangan undangundang, hasil-hasil penelitian, hasil karya dari kalangan hukum, dan seterusnya.

\section{c. Bahan Hukum Tersier}

Bahan Hukum Tersier yaitu bahan hukum yang memberikan petunjuk maupun penjelasan terhadap bahan hukum primer dan sekunder, seperti kamus, ensiklopedia, indeks kumulatif, dan seterusnya ${ }^{7}$.

\section{Teknik Pengumpulan Bahan Hukum}

Teknik pengumpulan bahan penelitian hukum yang digunakan dalam penelitian ini dengan cara mengumpulkan, mengidentifikasi, menginventirisasi peraturan perundangundangan, meneliti bahan pustaka, dan menyeleksi ragam bahan yang mengandung sudut pandang yang berbeda.

\footnotetext{
5 Ibid., Hlm. 302

6 Zainuddin Ali, Metode Penelitian Hukum, Sinar Grafika, Jakarta, 2009, Hlm.2

7 Soerjono Soekanto dan Sri Mamudji, Penelitian Hukum Normatif, Rajawali Pers, Jakarta, 2010, Hlm. 13
}

\section{PEMBAHASAN}

A. Modus Operandi Pencemaran Nama Baik Melalui Media Sosial Berdasarkan Pasal 27 ayat (3) Undang-Undang Nomor 11 Tahun 2008

Seiring dengan perkembangan zaman pada saat ini, maka berkembang pula jenis-jenis kejahatan yang baru. Sarana dan media untuk melakukan tindak kejahatan ini semakin luas dan beraneka ragam. Salah satunya adalah melalui media sosial internet. Didalam Pasal 27 ayat (3) Undang-Undang Nomor 11 Tahun 2008 telah diatur sedemikian rupa, larangan content yang memiliki muatan penghinaan dan atau pencemaran nama baik ini sebenarnya berusaha untuk memberikan perlindungan atas hak-hak seseorang atau individu, dimana setiap pengguna informasi melalui media yang menyangkut data pribadi seseorang harus dilakukan atas persetujuan orang tersebut. Tidak hanya didalam undang-undang Informasi dan Transaksi Elektronik saja yang mengatur tentang pencemarna nama baik Kitab Undang-Undang Hukum Pidana juga mengatur hal tersebut. Pasalpasal mengenai penghinaan dan pencemaran nama baik antara lain Pasal 310 dan 311 Kitab Undang-Undang Hukum Pidana.

\section{Modus Operandi Cyber Crime}

Dalam bahasa latin modus operandi berarti cara bertindak atau prosedur. Jadi modus operandi adalah cara melaksanakan, cara bertindak. Sehingga dapat pula disimpulkan modus operandi pencemaran nama baik melalui media sosial adalah cara melaksanakan, atau cara-cara bagaimana pencemaran nama baik melalui media sosial itu dilakukan.

\section{Kategori Yang Termasuk Pencemaran Nama Baik}

Sedangkan kategori yang dimaksudkan dengan pencemaran nama baik diatur dalam Kitab UndangUndang Hukum Pidana yang di sebut dengan "penghinaan" terdapat pada Bab XVI tentang penghinaan yang termuat dalam Pasal 310 s.d 321 Kitab Undang-Undang Hukum Pidana. 
Dalam konten penghinaan yang dipermasalahkan haruslah ada kejelasan identitas orang yang dihina. Identitas tersebut harus mengacu kepada orang pribadi (natural person) identitas dapat berupa gambar (foto), username, riwayat hidup seseorang, atau informasi lain yang berhubugan dengan orang tertentu yang dimaksud.

Apabila ada seseorang yang merasa bahwa kalimat tersebut ditujukan untuk dirinya maka kecuali pelaku mengaku demikian, diperlukan usaha besar untuk mengaitkan antara konten serta tujuan penulisannya dan korban. Kriteria yang lebih objektif untuk menilai hubungan antara muatan dari informasi atau dokumen elektronik yang dianggap menghina atau mencemarkan nama baik seseorang dan korban dapat dibangun berdasarkan konten dan konteks dari tiap-tiap kasus. Konten yang dipermasalahkan dapat dinilai dari sisi bahasa. Sedangkan konteksi dapat dinilai dari sisi sosial maupun psikologi. ${ }^{8}$

B. Penegakan Hukum Pidana Terhadap Tindak Pidana Pencemaran Nama Baik ditinjau dari Aspek Yuridis Menurut Undang undang Informasi dan Transaksi Elektronik Nomor 11 Tahun 2008

\section{Kasus dan Analisis}

Tindak pidana pencemaran nama baik yang dilakukan oleh Wahyu Muharram. Kasus yang dialami Wahyu merupakan tindak pidana Pencemaran Nama Baik yang dilakukan oleh Wahyu terhadap perorangan (individu).

Wahyu adalah mahasiswa tingkat akhir pada salah satu universitas di Jember. Kejadian tersebut bermula saat salah satu anak buah Tri Basuki meminjam sebuah barang berupa kunci stem, setelah selesai digunakan anak buah Tri Basuki tersebut tidak mengembalikan kunci tersebut kepada Wahyu melainkan dikembalikan kepada Tri Basuki. Wahyu sebagai pemilik kunci stem

\footnotetext{
${ }^{8}$ Josua Sitompul, Op.cit, hlm. 180-181.
}

tersebut meminta kepada Tri Basuki untuk mengembalikan kunci stem tersebut.'

Tri Basuki menolak untuk memberikan kunci stem tersebut dengan alasan kunci stem tersebut adalah miliknya. Karena merasa kesal Wahyu menuliskan katakata yang tidak sepantasnya dituliskan pada akun jejaring sosial miliknya. Kata-kata itu ditujukan kepada Tri Basuki yang merupakan seorang pelatih senior grup marching band di kota Jember.

Kata-kata yang dituliskan oleh Wahyu akhirnya diketahui oleh Tri Basuki. Wahyu yang merasa tulisan yang dibuatnya tidak pantas untuk ditulis di jejaring sosial, maka Wahyu mempunyai itikad baik dengan menghapus tulisan tersebut dan menggantinya dengan tulisan permintaan maaf yang juga dituliskan di akun jejaring sosial miliknya selama satu minggu.

Tri Basuki merasa nama baiknya telah dicemarkan oleh Wahyu, maka Tri Basuki membawa kasus tersebut ke jalur hukum. Setelah melalui proses pemeriksaan yang dilanjutkan pada proses peradilan, Wahyu dijatuhi vonis oleh hakim Pengadilan Negeri Jember selama 3 bulan penjara dengan masa percobaan selama 6 bulan. Dengan putusan tersebut, Wahyu Muharram tidak perlu menjalani pidana kurungan, karena hukuman kurungan hanya akan dilakukan jika dalam masa percobaan enam bulan tersebut Wahyu Muharram melakukan suatu tindak pidana.

Kasus pencemaran nama baik yang dilakukan oleh Wahyu, penyidik polisi maupun jaksa penuntut umum tidak menggunakan Undang-undang khusus, yaitu Undang-undang Informasi dan Transaksi elektronik (UU ITE) melainkan menggunakan Pasal 310 dan Pasal 311 Kitab Undang-undang Hukum Pidana (KUHP). ${ }^{10}$

Berdasarkan dua contoh kasus tersebut terdapat beberapa permasalahan yaitu dapat dilihat dari dasar penjatuhan tuntutan dan hukuman yang berbeda antara kasus Prita dan kasus Wahyu yang melakukan

\footnotetext{
${ }^{9}$ http://www.tempo.co/read/news/2010/02/22/ 058227663/Sidang-Pencemaran-Nama-LewatFacebook-Jalan-Terus, diakses pada 27 September 2016 pukul 23.30.

10 http://indonesiabuku.com/?p=4490, diakses pada 27 September 2016 pukul 23.30.
} 
Tindak pidana pencemaran nama baik. Prita Mulyasari dituntut dengan menggunakan Pasal 27 ayat 3 Undang-undang Nomor 11 Tahun 2008 dengan ancaman 6 tahun penjara dan membayar kerugian sebesar Rp. 304.000.000.- (Tiga ratus empat juta rupiah), sedangkan Wahyu divonis tiga bulan penjara dengan masa percobaan enam bulan menggunakan Pasal 310 dan Pasal 311 Kitab Undang-undang Hukum Pidana (KUHP). Perbedaan tersebut dikarenakan Prita Mulyasari mencemarkan nama baik Rumah Sakit Omni Internasional yang merupakan salah satu korporasi yang akibat dari perbuatannya tersebut mengakibatkan potensi kerugian materiilnya dapat lebih besar daripada kerugian yang dapat terjadi akibat pencemaran nama baik terhadap perorangan yang dilakukan oleh Wahyu Muharram.

\section{Faktor-faktor yang Menghambat Penegakan Hukum Terhadap Tindak Pidana Pencemaran Nama Baik}

Faktor-faktor yang dimaksud, dapat dianalisis hambatan-hambatan dalam implementasi Undang-undang Informasi dan Transaksi Elektronik (UU ITE) secara global, yaitu sebagai berikut:

1. Faktor Hukum

a) Adanya mekanisme penyelesaian sengketa secara perdata tanpa sinkronisasi dengan mekanisme penegakan hukum pidana dalam Undang-undang Informasi dan Transaksi Elektronik (UU ITE) akan menjadikan proses penegakan hukum cyber crime bertentangan karena tidak dijelaskan secara eksplisit tentang dianutnya asas subsidiaritas sebagaimana dalam Undangundang Nomor 23 tahun 1997 tentang pengelolaan lingkungan hidup, sehingga jelas (dalam kondisi bagaimana) proses pidana maupun perdata seharusnya dijalankan. (Vide Pasal 18 ayat (4), ayat (5) dan Bab VII Undang-undang Informasi dan Transaksi Elektronik (UU ITE)).

b) Masih terdapat ambiguitas dalam beberapa delik pidana pada Undang- undang Informasi dan Transaksi Elektronik (UU ITE), antara lain : Pada Pasal 27 ayat (3), batasan tentang unsur-unsur penghinaan dan pencemaran nama baik tidak terlalu jelas sehingga menimbulkan ambiguitas sehingga interpretasinya akan sangat tergantung pada subyektifitas dari pelapor atau korban, penegak hukum sendiri dan ahli bahasa. Oleh karena itu materi dalam pasal tersebut banyak mendapatkan prokontra dari masyarakat terutama dikaitkan dengan isu kebebasan pers yang terancam dengan adanya pasal tersebut, sebagimana dinyatakan dalam Pasal 1 ayat (11) Undang-undang No. 40 tahun 1999 tentang Pers. ${ }^{11}$

2. Faktor Penegak Hukum

Pengetahuan dan kemampuan penegak hukum dalam bidang teknologi informasi dan komunikasi sangat berpengaruh terhadap penanganan kasus cyber crime. Criminal Justice System (CJS) yang terdiri dari Polisi, Jaksa dan Hakim yang menangani tindak pidana cyber crime harus memiliki kompetensi khusus di bidang tersebut, tidak dapat disamakan dengan penegak hukum yang menangani tindak pidana konvensional. Selain hal tersebut kesepahaman tentang interpretasi delik-delik pidana dalam Undangundang Informasi dan Transaksi Elektronik (UU ITE) oleh elemen CJS dimaksud juga sangat vital dalam proses proses peradilan tindak pidana cyber crime. Apabila pada tingkat penyidikan, penyidik tidak sepaham dengan jaksa, maka akan mengakibatkan berkas perkara terhambat P-21. Demikian juga apabila tidak ada persepsi yang sama antara jaksa dengan hakim, dapat saja mengakibatkan seorang terdakwa yang seharusnya terbukti justru mendapat vonis bebas. Penegak hukum tidak dapat berdiri sendiri dalam penanganan cyber crime dikarenakan keterbatasan dalam beberapa hal seperti halnya kemampuan teknis tentang teknologi informasi dan komunikasi serta perlengkapan yang dibutuhkan dalam melakukan pelacakan (tracking) terhadap pelaku cyber crime.

3. Faktor Sarana/Fasilitas

Faktor sarana/fasilitas khusus untuk kepentingan penyidikan tindak pidana gyber crime mutlak diperlukan, khususnya oleh penyidik Polri karena pada tahap penyelidikan dan/atau penyidikan. Sebenarnya dasar kekuatan pembuktian tindak pidana cyber crime mulai dibangun. Hal tersebut terkait terutama dalam rangka

\footnotetext{
${ }^{11} \mathrm{http}: / /$ politikana.com, "Pro kontra pasal penghinaan di UU ITE dan KUHP", diakses pada tanggal 26 September 2016 Pukul 20.00.
} 
analisis dan pengolahan digital evidence, meliputi software dan bardware (computer forensic tools kit).

4. Faktor Masyarakat

Dukungan masyarakat terhadap aparat penegak hukum sangat diperlukan dalam penanganan tindak pidana cyber crime, baik secara individu maupun oleh komunitaskomunitas tertentu, khususnya di bidang teknologi dan informasi, yang formal (APJII, AWARI dll) maupun underground (Jasakom, Yogya Carder, dll). Masyarakat dapat berperan serta aktif dalam memberikan informasi kepada penyidik Polri tentang suatu peristiwa yang diduga sebagai tindak pidana cyber crime.

e. Faktor Budaya

Saat ini, muncul rumor Undangundang Informasi dan Transaksi Elektronik (UU ITE) dianggap tidak memiliki kekuatan hukum, ${ }^{12}$ karena masyarakat menganggap bahwa Undang-undang Informasi dan Transaksi Elektronik (UU ITE) sebenarnya sudah cukup akomodatif namun penegak hukum belum maksimal.

\section{KESIMPULAN}

Atas dasar pembahasan yang telah dijelaskan pada bab-bab sebelumnya, penulis dapat mengambil simpulan bahwa :

1. Modus operandi yang dilakukan oleh pelaku tindak pencemaran nama baik melalui media sosial, merupakan salah satu cerminan bahwa masyarakat Indonesia belum memahami makna penggunaan media sosial secara baik dan bertanggung jawab. Selain mempunyai hak kita juga harus mengetahui kewajiban apa saja yang harus kita laksanakan sebelum mendapatkan hak tersebut, sama halnya dengan menggunakan media sosial, penggunaan media sosial merupakan hak tiap-tiap masyarakat pada saat ini, namun sebagai penggunanya tentu kita juga harus mengetahui kewajiban untuk mengharagai orang lain. Banyaknya modus operandi yang digunaan oleh pelaku cyber crime, maka perlunya kehati-hatian dalam menggunakan media sosial agar kita tidak menjadi salah satu dari pelaku yang dapat

12 http:// forum.detikinet.com, "Akhirnya undang-undang itu disahkan juga”, diakses pada tanggal 26 September 2016. merugikan orang banyak. Dalam UndangUndang Nomor 11 Tahun 2008 tentang Informasi dan Transaksi Elektronik, tidak diatur secara jelas memahami batasan dalam kebebasan berpendapat. Jika kita melihat impelementasinya seakan-akan diatur, maka jelas bahwa kita benar-benar membutuhkan aturan yang baru tentang tindak pidana pencemaran nama baik dalam undang-undang Informasi dan Transaksi Elektronik. Bagi masyarakat harus lebih mehami arti kebebasan berpendapat yang diberikan oleh negara, dan menggunakan kebebasan tersebut dengan bertanggung jawab. Bukan untuk membatasi kebebasan tersebut melainkan untuk memberi peringatan atau tindakan Preventif bagi masyarakat agar lebih berhati-hati dalam menggunakan media sosial dalam berkomunikasi dan memberikan tindakan Represif bagi pelaku tindak pidana pencemaran nama baik melalui media sosial.

2. Undang-undang Nomor 11 Tahun 2008 Tentang Informasi dan Transaksi Elektronik (UU ITE) dari tahun dibentuknya sampai sekarang, tingkat efektifitasnya tidak maksimal. Hal tersebut dapat dilihat dari masih adanya kasuskasus penyalahgunaan Teknologi Informasi dan Transaksi Elektronik, yang masih dituntut dengan menggunakan Pasal-pasal yang terdapat di KUHP.

3. Penegakan hukum pidana terhadap tindak pidana pencemaran nama baik terdapat beberapa faktor-faktor yang menjadi penghambat. Faktor-faktor penghambat tersebut antara lain:
a. Hukum (Undang-undang);
b. Penegak Hukum, yakni pihak-pihak
yang membentuk maupun menerapkan hukum;
c. Sarana atau fasilitas yang mendukung penegakan hukum;
d. Masyarakat, yakni dimana hukum tersebut diterapkan; dan
e. Kebudayaan, yakni sebagai hasil karya cipta dan rasa yang didasarkan pada karsa manusia didalam pergaulan hidup




\section{E. DAFTAR PUSTAKA}

Abdul Wahid dan Mohammad Labib, 2010, Kejahatan Mayantara (cyber crime), cet. 2 , PT. Refika aditama, Bandung. 2010, Kejahatan Mayantara (cyber crime), cet. 2 , PT. Refika aditama, Bandung.

Abdulkadir Muhammad, 2004, Hukum dan Penelitian Hukum, PT. Citra Aditya Bakti, Bandung.

Adami chazawi, 2002, Pelajaran Hukum Pidana Bagian 1, Jakarta: PT Raja Gravindo Persada.

Agus Raharjo, 2002, Cybercrime: Pemahaman Dan Upaya Pencegahan Kejahatan Berteknologi. Citra Aditya Bakti, Bandung.

Andi Hamzah, 2004, Asas-Asas Hukum Pidana, Jakarta : PT. Rineka Cipta, cetakan kedua (edisi revisi).

1987, Aspek-aspek Pidana Dibidang Komputer, Sinar Grafika, Jakarta.

Bambang Sunggono, 2007, Metode Penelitian Hukum, PT. RajaGrafindo Persada, Jakarta.

C.S.T. Kansil dan Christine S.T. Kansil, 2007, Pokok-pokok Hukum Pidana, Jakarta : PT Pradnya Paramita,

Dikdik M. Arief Mansur dan Elisatris Gultom, 2009, CYBER LAW: Aspek bukum Teknologi Informasi, PT. Refika Aditama, Bandung.

E.Y. Kater dan S.R. Sianturi, 1992, Asas-asas Hukum pidana di Indonesia dan Penerapannya, Jakarta : Alumni AHMPTHM.

Johnny Ibrahim, 2005, Teori dan Metode Penelitian Hukum Normatif, Bayumedia Publishing, Jakarta.

Juwono Sudarsono, 1992, "Ilmu, Teknologi, dan Etika Berprofesi: Pandangan SosialPolitik,Masyarakat: Jurnal Sosiologi”, FISIP UI-Gramedia, Jakarta.

Laden Marpaung, 1997, Tindak pidana terhadap kehormatan, pengertian dan penerapannya, Jakarta : PT Raja Gravindo Persada.

Moeljatno, 2002, Asas-asas Hukum Pidana, Jakarta: PT Rineka Cipta. 68

P.A.F. Lamintang, 1997, Dasar-Dasar Hukum Pidana Indonesia, Bandung : PT. Citra Aditya Bakti.
Peter Mahmud Marzuki, 2008, Pengantar Ilmu Hukum, Jakarta : Prenada Media Group.

Roeslan Saleh, 1983, Perbuatan Pidana dan Pertanggungjawaban Pidana : Dua Pengertian Dasar Dalam Hukum Pidana, cet 3, Aksara Baru, Jakarta.

Sutan Remy Syahdeini, 2009, Kejahatan dan Tindak Pidana Komputer, PT. Pustaka Utama Grafiti, Jakarta. 2009, Kejahatan dan Tindak Pidana Komputer, PT. Pustaka Utama Grafiti, Jakarta.

Siswanto Sunarso, 2009 Hukum Informasi dan Transaksi Elektronik; Studi Kasus: Prita Mulyasari, Rineka Cipta.

Soerjono Soekanto, 1983 Faktor-faktor yang Mempengarubi Penegakan Hukum, PT.Raja Grafindo Persada, Jakarta. 1982, Sosiologi Suatu Pengantar, CV. Rajawali, Jakarta.

Soerjono Soekanto dan Sri Mamudji , 2010, Penelitian Hukum Normatif, Rajawali Pers, Jakarta.

Wawan Tunggal Alam, 2012, Pencemaran Nama Baik di Kehidupan Nyata dan Dunia Internet, wartapena, Jakarta.

Wirjono Prodjodikoro, 2003, Asas-Asas Hukum Pidana Di Indonesia, Bandung : PT. Refika Aditama, Edisi Ketiga Cetakan Pertama.

Zainuddin Ali, 2009, Metode Penelitian Hukum, Sinar Grafika, Jakarta 